Cita bibliográfica: Benítez-Aurioles, B. (2021). Uncertainty and tourism. A regional approach. Investigaciones Turísticas (22), pp. 52-68. https://doi.org/10.14198/INTURI2021.22.3

\title{
Uncertainty and tourism. A regional approach
}

\author{
Incertidumbre y turismo. Un enfoque regional
}

Beatriz Benítez-Aurioles (iD, University College London, España

bbaurioles@gmail.com

\section{ABSTRACT}

The aim of this article is to analyze and quantify the impact of uncertainty on tourist demand at a regional level. More specifically, with data corresponding to the period between 2000T1 and 2019T3, it estimates the elasticity of overnight stays in hotels in different Spanish Autonomous Regions in response to changes in the Economic Policy Uncertainty Index (EPU). The econometric analysis performed not only confirms the inverse relationship between tourist demand and uncertainty, but also detects patterns of behavior between regions that can be geographically grouped. In general, regions with a higher number of overnight stays per inhabitant tend to be more sensitive to uncertainty.

Keywords: uncertainty; tourism; overnight stays; Spanish regions.

JEL CLASSIFICATION: D81; L83; R12

\section{RESUMEN}

El objetivo de este artículo analizar y cuantificar el impacto que, a nivel regional, tiene la incertidumbre sobre la demanda turística. Más concretamente, con datos entre 2000T1 y 2019T3, se estima la elasticidad de las pernoctaciones en los hoteles de las distintas Comunidades Autónomas españolas ante cambios en el Índice de Política Económica (EPU). Los resultados de los análisis econométricos realizados, además de confirmar la relación inversa entre demanda turística y la incertidumbre, detectan patrones de comportamiento similares entre regiones que pueden agruparse geográficamente. En general, las regiones con mayor número de pernoctaciones por habitante tienden a ser más sensibles a la incertidumbre.

Palabras clave: incertidumbre; turismo; pernoctaciones; regiones españolas.

CLASIFICACIÓN JEL: D81; L83; R12 


\section{INTRODUCTION}

Recently, the fact that uncertainty affects tourist demand has been demonstrated, but there is no empirical evidence on its effects at a territorial level. That is, precisely, the objective of this paper: to analyze the spatial effects of uncertainty changes in tourist demand. More specifically, taking as a reference the Spanish regions, the sensitivity of overnight stays in hotels to changes in uncertainty will be quantified and, on that basis, we will identify some common patterns of behavior that are geographically grouped.

The structure of this work is as follows. We start with a literature review. Next, the theoretical framework, the methodology and the data are introduced. Afterwards, we perform a descriptive analysis. The subsequent section is devoted to the presentation of econometric estimations and a discussion. We close with conclusions, implications, limitations and future lines of research related to this work.

\section{LITERATURE REVIEW}

The influence of uncertainty on economic performance-and in particular, on consumption-has a long-standing tradition and had already been put forward in the work of Keynes (1936). Nonetheless, acknowledging its role in explaining tourist demand variations is a much more recent phenomenon. Previously, the effects of tourism of some events that increase uncertainty had been analyzed. In fact, after certain seminal contributions that attempt to quantify the impact of certain events, such as the civil unrest in France, 1968, on the fall of tourist demand (White, 1985), there has been a proliferation of macro-level research on the effect of terror attacks on the number of tourists, or on the income of affected countries (Tremblay, 1989; Enders \& Sandler, 1991; Enders et al., 1992; Pizam \& Fleischer, 2002; LlorcaVivero, 2008; Yaya, 2009; Feridun, 2011; Thompson, 2011; Raza and Jawaid, 2013; Saha \& Yap, 2014; Bassil et al, 2015; Buigut \& Amendah, 2016; Neumayer \& Plümpler, 2016; Ajogbeje, Adeniyi \& Folarin, 2017; Buigut et al, 2017; Karl et al., 2017; Liu and Pratt, 2017; Buigut, 2018; Samitas et al, 2018; Bassil et al., 2019). In some cases, political instability indicators have been taken as explanatory variables (Fleischer \& Buccola, 2002; Neumayer, 2004; Saha \& Yap, 2014; Ghaderi et al., 2017). There is also work at the microeconomic level about the joint effect of political instability and terrorism on the functioning of the p2p market for tourist accommodation (Benítez-Aurioles, 2019a). Nevertheless, knowledge on the role of uncertainty on tourist demand has long been limited by the absence of direct indicators that permit the quantification of uncertainty. It was stemming from the proposal of an index of economic policy uncertainty (EPU) developed by Baker et al. (2016) when work on that matter began. Essentially, the EPU index is constructed through the frequency with which some words (for example, uncertainty, economic or deficit) appear in newspapers of well-known relevance.

Ever since then, the EPU index has frequently been used to quantify the impact of uncertainty on certain variables, markets, or economies as a whole (Colombo, 2013; Arouri et al., 2014; Benítez-Aurioles, 2019b; Karnizova \& Li, 2014; Brogaard and Detzel, 2015; Dai et al. 2017; Aye, 2018; Chow et al., 2018; Ashraf \& Shen, 2019; Cheng et al., 2019; Hsieh et al., 2019; Ivanovski \& Churchill, 2019; Ma et al., 2019; Morales \& Andreosso-O'Callaghan, 2019; Li et al., 2020; Nilavongse et al., 2020). In parallel, the first econometric studies using the EPU index as an argument to explain changes in tourist demand emerged (Table 1). 
Table 1. Econometric studies using the EPU as an explanatory variable for tourist demand

\begin{tabular}{|c|c|c|c|c|}
\hline Authors & Dependent Variable & Geographical Frame & Time Frame & Findings \\
\hline $\begin{array}{l}\text { Dragouni, Filis, Gavriilidis } \\
\text { and Santamaria (2016) }\end{array}$ & Number of tourists & From USA & $1996-2013$ & $\begin{array}{l}\text { A shock to the EPU index transmits spillover effects to the USA } \\
\text { outbound tourism demand }\end{array}$ \\
\hline Gozgor and Ongan (2017) & Tourism spending & In USA & $1998-2015$ & $\begin{array}{l}\text { A higher level of EPU index leads to significant declines in tourism } \\
\text { spending in the long run }\end{array}$ \\
\hline Demir and Gozgor (2018) & Number of tourists & From 15 countries & $1996-2014$ & $\begin{array}{l}\text { Higher level of EPU index in a country decreases outbound } \\
\text { tourism }\end{array}$ \\
\hline Gozgor and Ongan (2018) & Number of tourists & From Japan to USA & $1996-2015$ & $\begin{array}{l}\text { One standard deviation increase in the EPU index leads to a } 4.7 \% \\
\text { decrease in the number of Japanese tourist arrivals to the USA in } \\
\text { the long run }\end{array}$ \\
\hline $\begin{array}{l}\text { Madanoglu and Ozdemir } \\
\text { (2019) }\end{array}$ & $\begin{array}{l}\text { Occupancy rate, } \\
\text { ADR, and RevPAR }\end{array}$ & To USA & 2004-2013 & $\begin{array}{l}\text { EPU index has a persistent negative impact on hotel operating } \\
\text { performance }\end{array}$ \\
\hline $\begin{array}{l}\text { Tsui, Balli, Tan, Lau, and } \\
\text { Hasan (2018) }\end{array}$ & Business visitors & $\begin{array}{l}\text { From } 8 \text { countries to } \\
\text { New Zealand }\end{array}$ & $2008-2015$ & $\begin{array}{l}\text { EPU index has statistically significant impact on the country's } \\
\text { business tourism flows }\end{array}$ \\
\hline Demir and Ersan (2018) & $\begin{array}{l}\text { Performance of the } \\
\text { tourism sector }\end{array}$ & Turkey & $2002-2013$ & $\begin{array}{l}\text { Stock returns of the Turkish tourism companies depend on } \\
\text { domestic and international EPU index }\end{array}$ \\
\hline $\begin{array}{l}\text { Işik, Sirakaya-Turk, and } \\
\text { Ongan (2019) }\end{array}$ & Number of tourists & $\begin{array}{l}\text { From Canada and } \\
\text { Mexico to USA }\end{array}$ & 1996-2017 & Increases in the EPU index lead to decreases in tourism demand \\
\hline Aslan and Altinöz (2020) & $\begin{array}{l}\text { Performance of the } \\
\text { tourism sector }\end{array}$ & Turkey & $1997-2017$ & $\begin{array}{l}\text { An increase in the global and European EPU affects negatively } \\
\text { the Borsa Istanbul tourism index in the short and long run. }\end{array}$ \\
\hline
\end{tabular}


As far as we are aware of, the first study to include the EPU index as an explanatory variable for tourist demand was that by Dragouni et al. (2016). Concretely, using a VAR model, the authors confirm the drop-rebound-overshoot effect, postulated by Bloom (2009), so that the increase of uncertainty would lead travelers to postpone their travel plans in periods of economic recession. For their part, Gozgor and Ongan $(2017,2018)$ applied the unit root and a cointegration test and found that the increase in the EPU index is associated with a reduction in both the number and the expenditure of tourists. Demir and Gozgor (2018) estimate the empirical models by using the fixed-effects and the bias-corrected least square dummy variable (LSDV) and noted, once again, that higher level of EPU in a country decreases outbound tourism. The impact of growth in the EPU index on hotel operating performance has also been attested (Madanoglu \& Ozdemir, 2019), as well as its impact on performance of the tourism sector in general (Demir \& Ersan, 2018; Aslan \& Altinöz, 2020). At a more concrete level, Tsui et al. (2018) applied a panel data gravity model and found a statistically significant impact of the EPU index on business travelers. More recently, Işik et al. (2019) estimated equations in regression and ECM forms to conclude, after noting that an increase in the EPU index lead to decreases in tourism demand, that the EPU index should be included as an additional independent variable when modeling tourist demand.

In other words, enough empirical evidence has been cumulated in recent years that relates economic uncertainty to basic variables in the tourism market and, more concretely, to tourist demand. However, no analysis at the regional level had been made thus far. In fact, available research uses aggregate data from countries without specifying their consequences at the territorial level. This paper intends to bridge this gap analyzing the relationships between uncertainty and tourist demand at a regional level.

\section{THEORETICAL FRAMEWORK, METHODOLOGY AND DATA}

The theoretical framework is built on the basis of the conjecture by Keynes (1936): "the propensity to consume may be sharply affected by the development of extreme uncertainty concerning the future and what it may bring forth". Since then, models have been presented in which uncertainty always leads a prudent agent to reduce consumption (Eeckhoudt et al., 2005) no matter the timing of the resolution of uncertainty; and evidence was put forward that companies and homes postpone their investment and consumption decision when political uncertainty grows (Giavazzi \& McMahon, 2012). In this context, we can understand how uncertainty affects tourist demand. Uncertainty shocks affect the consumption of households that react by postponing certain purchases - in particular, those related to tourist demand, like accommodation or transportation, that are costly to cancel.

Given the fundamental role of tourism flows in decision making-both for company management and economic policy-the study of tourist demand has received researchers' special attention. Among the different models used, those based in a single equation with aggregate data have a long-standing tradition and have been widely utilized. Usually, the dependent variable is the number of tourists or their expenditure. And among the independent 
variables we often find, among others: the prices in the destination and in substitute destinations, transportation costs, income in the sending market, and the exchange rate. More recently, as previously mentioned, the EPU index has been incorporated too.

Our proposal is the analysis of overnight stays in Spain made over time by residents in different regions. This option allows us to simplify the empirical model, as we focus our study in the effect of uncertainty in Spain on tourist demand from Spanish residents themselves. Given that this would be a dynamic model, the assumptions of Ordinary Least Squares regression for regressor exogeneity would be violated. The Autoregressive-Distributed Lag (ARDL) model presented by Pesaran et al. (2001) is used to explore the cointegrated relationship between the variables. It also has the advantage of estimating both short and long run parameters. This is also the technique used in Aslan and Altinöz (2020) to analyze the connection between the EPU and stock returns of tourism companies in Turkey. Our ARDL(4, 0, 0) formulation is as follows,

$$
\begin{gathered}
\operatorname{lOSH}_{i, t}=\beta_{i} \operatorname{lOSH}_{i, t-1}+\sum_{j=1}^{3}\left(\delta_{i j} \Delta \operatorname{lOSH}_{i, t-j}+\theta_{i} E C_{i, t-j}\right)+ \\
+\gamma_{i} l N D I_{t}+\delta_{i} l E P U_{t}+c_{i}+\varepsilon_{i, t}
\end{gathered}
$$

where $\mathrm{IOSH}_{i, t}$ represents the natural logarithm of the number of overnight stays of Spanish residents in hotel establishments of region (hence $\mathrm{IOSH}_{i, t-1}$ is its one-quarter lagged term); $\Delta l O S H_{i, t-j}$ is the difference term of $l O S H$ in time $t-j$ with respect to the previous period (quarter), $t-j-1 ; E C_{t-j}$ is an error correction term; $l N D I_{t}$ stands for the logarithm of the National Disposable Income (NDI) in Spain; $l E P U_{t}$ in $t$ is the logarithm of the EPU index in Spain in $t ; c_{i}$ is a regression intercept that varies by Autonomous Community; and $\varepsilon_{i, t}$ is a stochastic error term. The set $\left(\beta_{i}, \delta_{i j}, \theta_{i}, \gamma_{i}, \delta_{i}\right)$ for $i=1, \ldots 18$ (the Autonomous Communities and Spain as a whole) and $j=1,2,3$, are the coefficients to estimate, of which that in front of $l E P U_{t}\left(\delta_{i}\right)$ is that of interest. Data covers the period 2000T1-2019T3. The information in comes from the Encuesta de Ocupación Hotelera, published monthly by the INE (2020a). The quarterly data has been calculated aggregating that of the corresponding months.

The EPU index used is based, therefore, on the frequency with which certain words associated with uncertainty appear in newspapers published in Spain. That is, it tries to capture the uncertainty perceived by Spanish people, which explains why it is used as proxy variable of tourist demand for hotel accommodation of residents.

The EPU refers to Spain, and is available in Economic Policy Uncertainty (2020). The series is based on the methodology proposed by Ghirelli et al. (2019). In reality, it is an adaptation of the EPU index by Baker et al. (2016) to the Spanish case. On the one hand, the number of newspapers considered was expanded to seven: El País, El Mundo, La Vanguardia, ABC, Expansión, Cinco Días, and El Economista (only the two first were considered for the Spanish case by Baker et al.). On the other hand, Dow Jones' Factiva service is employed to search a broader set of words in every journal, which can be grouped in three categories: Uncertainty (inciert* or incertidumbr* or inestabl* or inestabilidad/inestabilidades or riesgo/riesgos); Economy (economic* or economía); and Policy (Parlamento or Moncloa or gobierno central 
or Hacienda or Comisión Europea or déficit or presupuest* or gasto público/gastos públicos or deuda pública/deudas públicas or política fiscal/políticas fiscales or política monetaria/ políticas monetarias or Banco Central Europeo/BCE or Banco de España/BdE or legislación/ legislaciones or reforma/reformas or norma/normas or normativ* or regulación/regulaciones or reglamento/reglamentos or ley/leyes). In this case, the quarterly data of the series is calculated as the average of the corresponding months.

INDI is contained in the quarterly regional accounts published by the INE (2020b), with seasonally and working-day adjusted data. Our $\operatorname{ARDL}(4,0,0)$ model fits a linear regression model of IOSH on IEPU and INDI with no lags, and IOSH with one lag and three differences (or, alternatively parameterized, four level lags). Using the Bayesian information criterion, the optimal lag length was determined to be four lags on IOSH and none on IEPU. For IOSH this seemed logical, since four lags (quarters) cover a year and hence all the annual seasonality effects. For IEPU, we considered that maybe holidays planned in advance of more than one quarter could be common enough to justify including it in our estimations, but this seems not to be the case.

The expected results are a negative relationship of overnight stays with the EPU and a positive relationship with income and the lagged variable. An Augmented Dickey-Fuller test is carried out to test the null hypothesis that IOSH follows a unit root. The statistic exceeds the $1 \%$ critical value in all cases (with the exception of Madrid), which supports the alternative hypothesis that overnight stays in hotels in general is produced by a stationary process. As for the Granger causality test, reverse causality with regards to our variable of interest - that is, an effect in the direction from the log of overnight stays to the log of EPU, is only non-rejected in one case, that of Aragon.

\section{DESCRIPTIVE ANALYSIS}

At an aggregate level, the original series of overnight stays in hotels, as plotted in Figure 1, shows strong seasonality that reaches its maximum in summer (third quarter) and its minimum in winter (first quarter). Once the series is seasonally adjusted, through a moving average of order four, we can split it into three periods. From 2000T1 to 2008T1, the tendency is towards sustained growth that is accentuated from 2003T1 on and finds its inflexion point in 2008T1. Since then, at the time of the great recession, an accelerated descent begins, followed by somewhat of a stagnation, and a new decrease that lasts until 2014T1. After that date, the trend is increasing again until the historical maximum is reached at the end of the period. 
Figure 1. Evolution of hotel overnight stays of residents in Spain. Millions.

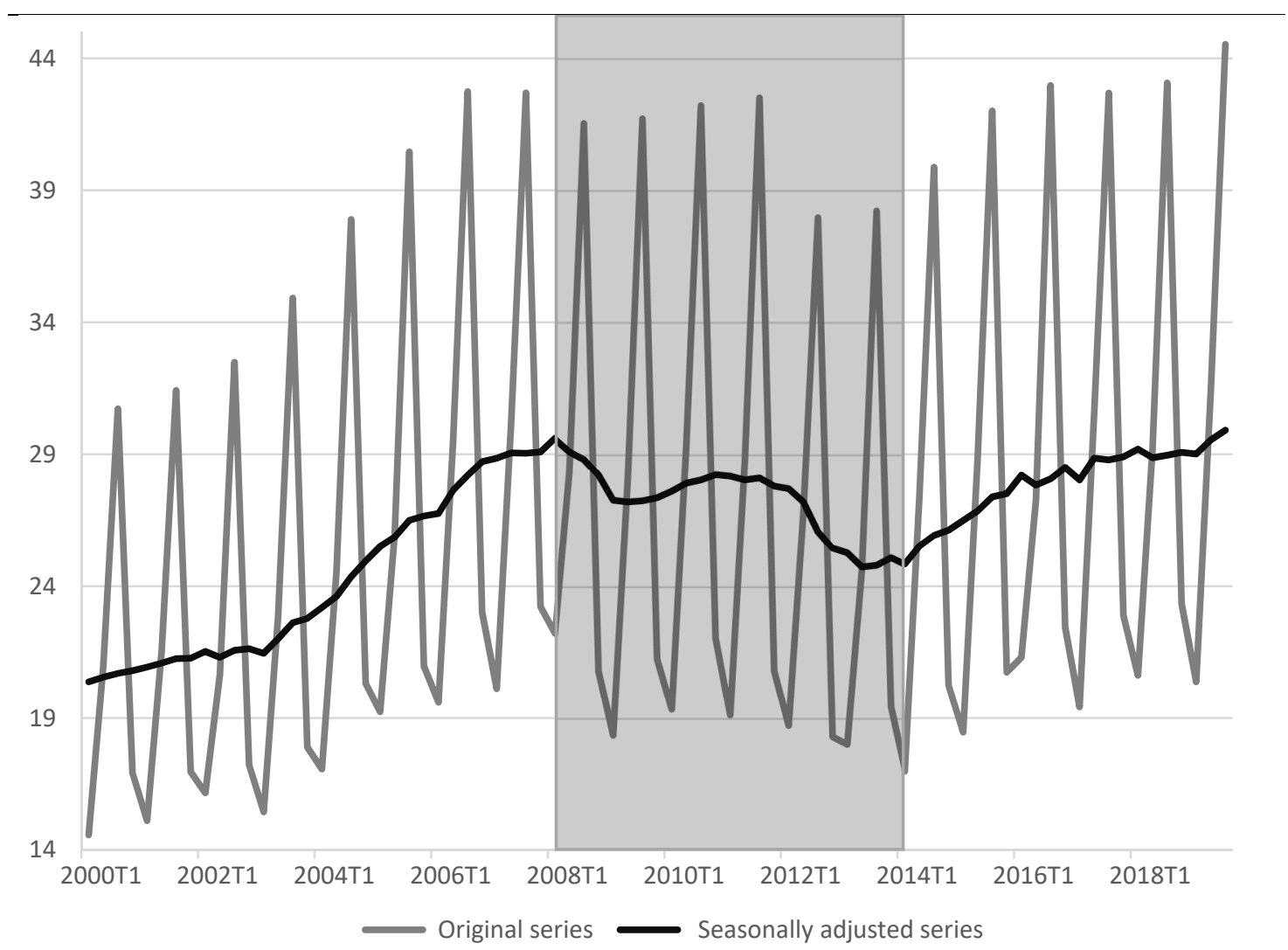

Source: Compiled from data from the Encuesta de Ocupación Hotelera (INE, 2020a).

However, aggregate data hides notable territorial differences. Table 1 lists the evolution of the percentage of the total represented by the overnight stays in each region at the start and at the end of the period considered. At the beginning, four regions absorbed $53.6 \%$ of the total of overnight stays of residents in Spain: Andalusia (17.6\%); Catalonia (15.3\%); Madrid (10.5\%); and the Valencian Community (10.2\%). At the end of the period, the joint percentage of these regions rose to $57.3 \%$ due to the better relative behavior of Andalusia and the Valencian Community, which reached shares of $23.7 \%$ and $14.2 \%$, respectively, while overnight stays in Catalonia and Madrid fell to $13.5 \%$ and $5.9 \%$ of the total. The Balearic and Canary archipelagos, that in $2000 \mathrm{~T} 1$ started at similar percentages ( $7.8 \%$ and $7.4 \%$ respectively) later diverged: the Canary Island increased up to $8 \%$, while the Balearic Islands went down to $5.1 \%$. Other regions that gain relative weight overall are the northern regions; Galicia, Asturias and Cantabria. Navarre's participation barely changes. On the contrary, La Rioja, Basque Country, Extremadura, Murcia, the two Castiles and Aragon experience declines in the period under consideration. 
Table 2. Percentage of overnight stays of residents in Spain of total. 2001T1-2019T1

\begin{tabular}{|l|c|c|c|}
\hline & \% of total 2000T1 [1] & \% of total 2019T1 [2] & [2]-[1] \\
\hline Andalusia & 17.6 & 23.7 & 6.0 \\
\hline Aragon & 4.7 & 3.3 & -1.4 \\
\hline Asturias & 1.7 & 3.2 & 1.5 \\
\hline Balearic Islands & 7.8 & 5.1 & -2.7 \\
\hline Canary Islands & 7.4 & 8.0 & 0.6 \\
\hline Cantabria & 1.3 & 2.5 & 1.1 \\
\hline Castile and Leon & 6.0 & 4.7 & -1.3 \\
\hline Castile-La Mancha & 3.1 & 2.0 & -1.1 \\
\hline Catalonia & 15.3 & 13.5 & -1.7 \\
\hline Valencian C. & 10.2 & 14.2 & 4.0 \\
\hline Extremadura & 1.9 & 1.4 & -0.5 \\
\hline Galicia & 5.1 & 6.6 & 1.5 \\
\hline Madrid & 10.5 & 5.9 & -4.6 \\
\hline Murcia & 2.6 & 1.9 & -0.8 \\
\hline Navarre & 1.1 & 1.1 & 0.1 \\
\hline Basque Country & 2.8 & 2.4 & -0.4 \\
\hline Rioja, La & 0.8 & 0.6 & -0.3 \\
\hline
\end{tabular}

Source: Compiled from data from the Encuesta de Ocupación Hotelera (INE, 2020a).

In addition to that, the evolution of the EPU index is reflected in Figure 2. We have highlighted some events that in principle can be associated to economic uncertainty. In this sense, the holding of general elections does not seem necessarily associated to an increase in uncertainty. Perhaps a special reference needs to be made to the elections held the 14th of May 2004, three days after the Atocha station bombings that accounted for nearly 200 deaths and approximately 2,000 injured. In this case, we can see a brief rebound in uncertainty that is quickly corrected downwards, similarly to what happened the 11th of September 2001 in the United States. It is also interesting to observe the coincidence of high relative uncertainty with one of the greatest ecological disasters of the world, when an accident of the tanker Prestige caused a massive oil spill that affected the coasts in the north of Spain. Still, we can identify two types of phenomena that coincide with spikes in the EPU index: economic and political. 
Figure 2. Evolution of the EPU index in Spain. 2000T1-2019T3

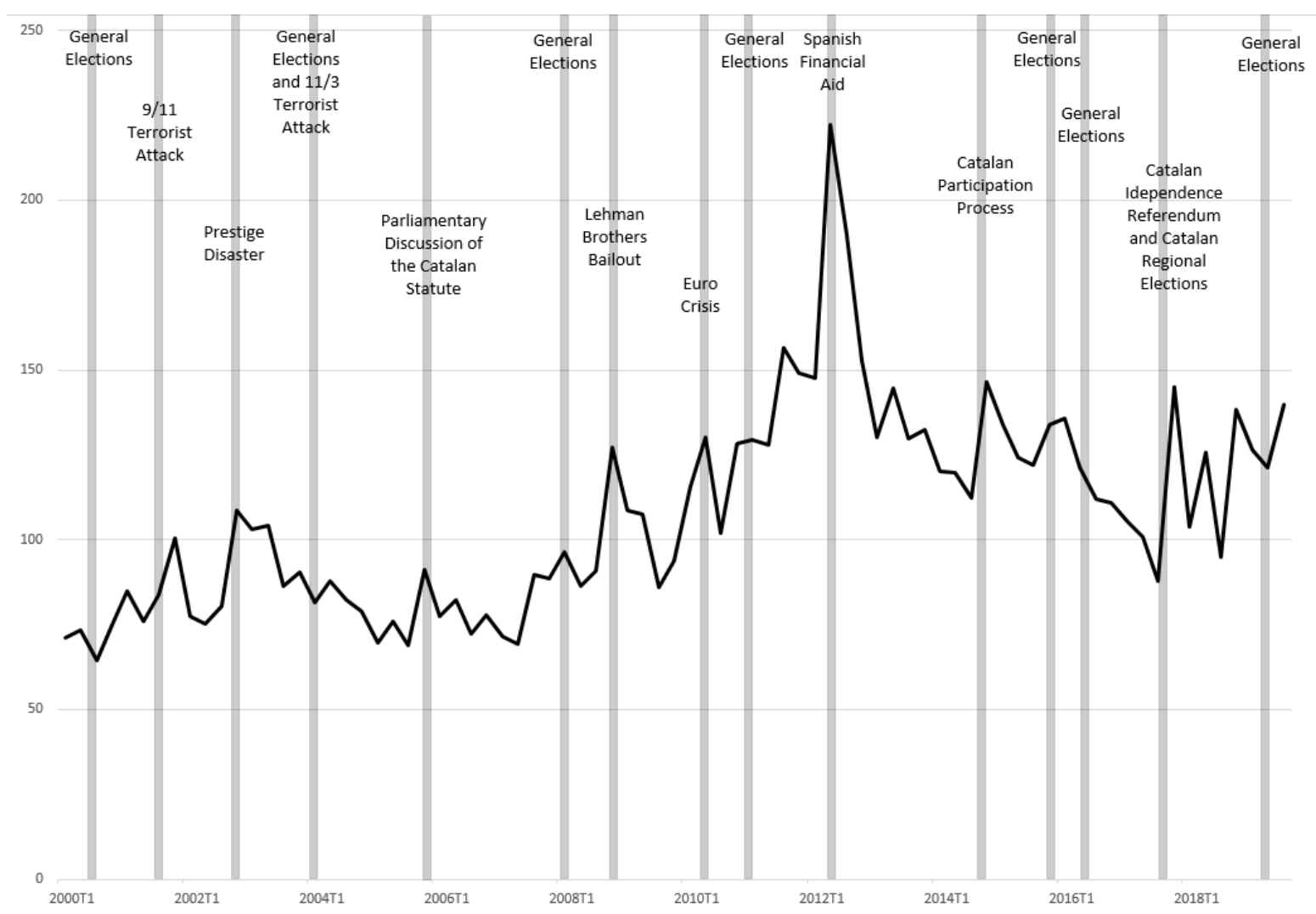

Source: Compiled from Economic Policy Uncertainty (2020)

Among the economic events related with high uncertainty levels, we highlight the following: the bankruptcy of Lehman Brothers the 15th of September 2008 that marked the beginning of the Great Recession; the Euro crisis that required the creation of the European Financial Stability Fund in May 2010, endowed with 750 thousand million euros, to save Greece from bankruptcy; and Spain's application in June 2012 to the European Union for financial aid to restore health in the banking system. The latter episode coincides with the highest level of the EPU index recorded in the period under study.

Besides that, the political occurrences that raised the level of uncertainty in Spain are related to the crisis in Catalonia. It is very significant that the EPU index increased in the last quarter of 2005, when Catalonia's new Statute of Autonomy was accepted for processing-with the support of all parties except the Popular Party, which presented an appeal for unconstitutionality the same day. It was precisely four years later when some of the articles of the new Statute were declared unconstitutional. Since then, popular support to independence grew and a chain of events that stirred uncertainty followed: the unofficial consultation on independence the 9th of November 2014; the holding of a referendum that had been declared illegal by the courts the 1st of October 2017; the unilateral declaration of independence the 27 th of October; recession of the autonomy by the Spanish parliament on the 28th of October; 
flight of the President of Catalonia and five of his Ministers to Belgium the 30th of October; the imprisonment of eight ministers of the Catalan government the 2nd of November; and elections in Catalonia that resulted in a new victory for the pro-independence parties the 21st of December. These circumstances, as pictured in Figure 2, caused an increase in the level and volatility of the EPU index since the last quarter of 2017.

Building on that descriptive analysis, we will the concrete relationship between the EPU index and overnight stays of residents quantify at the regional level in the next section.

\section{ESTIMATIONS AND DISCUSSION}

Table 2 contains the result of estimations of [1]. First, we note that the goodness of fit, measured by the adjusted, is high in all cases and the signs of the parameters are the expected, in general terms. Specifically, the inverse relationship between the EPU index and overnight stays is confirmed. At the aggregate level, the elasticity of overnight stays with respect to the EPU index is of 0.154. However, at a territorial level, we appreciate substantial differences. Broadly speaking, we can distinguish five main groups of regions in function of their elasticity values.

Firstly, we have the Balearic archipelago, where the sensitivity to overnight stays with respect to the EPU index practically doubles the national average. This is a more mature destination with an orientation to "sun and beach" tourism; and hence, faces a strongly seasonal demand. The weight of the services sector in this economy is very high-around $80 \%$ of the total gross added value (INE, 2020b), and within it, the activities related to tourism are particularly important as they represent approximately $30 \%$ of its employment (INE, 2020c). These data testify the high dependency of these islands to the evolution of the tourism sector. Our results show that said flows are also highly conditioned to economic uncertainty in relative terms. Interestingly, the elasticity of overnight stays to income is the lowest in this region (0.154 and insignificant). That is, the variations in overnight stays are fundamentally explained by the lagged dependent variable and by the EPU index.

Secondly, we have a grouping of a broad set of regions that have a higher-than-average elasticity of overnight stays to the EPU index compared to the national average, but not as high as that of the Balearic Islands. Some Communities of the north (Asturias, Cantabria and Galicia), the Canary Islands and Castile-La Mancha. Their elasticities range between 0.209 in the Canary Islands and 0.244 in Asturias. These are relatively heterogeneous regions in terms of size, location and economic structure. There does not seem to be a common pattern regarding elasticity of overnight stays to income, since in this group we observe values relatively high (Asturias, for instance, with 0.643 ) and others lower (Canary Islands, 0.235). In any case, despite their differences, all these regions have a high relative elasticity of overnight stays in hotels of residents with respect to movements in economic uncertainty, according to our estimations.

The third category includes regions around the average. In this case, we find, on the one hand, southern regions (Andalusia, Murcia) and on the other, northern inland regions 
Table 3. OLS regression $\operatorname{lOSH}_{t-1}$. Results. $N=79$

\begin{tabular}{|c|c|c|c|c|c|c|c|c|}
\hline & $\operatorname{lOSH}_{t-1}$ & $\Delta \mathrm{lOSH}_{t-1}$ & $\Delta l O S H_{t-2}$ & $\Delta \mathrm{lOSH}_{t-3}$ & $l N D I_{t}$ & $l E P U_{t}$ & Constant & $N$ \\
\hline Andalusia & $-.569 * *$ & $-.545 * * *$ & $-.706 * * *$ & $-.828 * * *$ & $.517 * *$ & $-.172 * * *$ & $1.114^{* *}$ & .982 \\
\hline Aragon & $-.399 *$ & $-.633 * * *$ & $-.660 * * *$ & $-.754 * * *$ & $.332 * *$ & $-.158 * *$ & .731 & .884 \\
\hline Asturias & $-.822 * * *$ & -.313 & $-.579 * * *$ & $-.718 * * *$ & $.643 * *$ & $-.244 * * *$ & $1.388 * *$ & .977 \\
\hline $\begin{array}{l}\text { Balearic } \\
\text { Islands }\end{array}$ & $-.307^{* *}$ & $-.721 * * *$ & $-.836 * * *$ & $-.887 * * *$ & .154 & $-.316 * * *$ & 1.521 & .974 \\
\hline Canary Islands & -.138 & $-.859 * * *$ & $-.927^{* * *}$ & $-.917 * * *$ & $.235^{* *}$ & $-.209 * * *$ & -.0346 & .97 \\
\hline Cantabria & $-.698 * * *$ & $-.429 * *$ & $-.636 * * *$ & $-.771 * * *$ & $.452^{* * *}$ & $-.244 * * *$ & $1.677^{* *}$ & .99 \\
\hline $\begin{array}{c}\text { Castile } \\
\text { and Leon }\end{array}$ & $-.461^{* *}$ & $-.341^{*}$ & $-.741 * * *$ & $-.553 * * *$ & $.271^{* *}$ & $-.133 * * *$ & $1.428 * *$ & .956 \\
\hline $\begin{array}{l}\text { Castile-La } \\
\text { Mancha }\end{array}$ & $-.489 * * *$ & $-.597 * * *$ & $-.702 * * *$ & $-.813^{* * *}$ & $.322^{* * *}$ & $-.224 * * *$ & $1.350 * * *$ & .932 \\
\hline Catalonia & $-.471^{*}$ & $-.607 * * *$ & $-.755 * * *$ & $-.833 * * *$ & .242 & $-.0939 *$ & $1.746^{*}$ & .974 \\
\hline Valencian C. & $-.685^{* *}$ & $-.455^{* *}$ & $-.645 * * *$ & $-.786 * * *$ & $.442 * *$ & $-.0981 * *$ & $1.971 * * *$ & .98 \\
\hline Extremadura & -.335 & $-.675^{* * *}$ & $-.792 * * *$ & $-.817 * * *$ & .213 & -.0551 & .699 & .918 \\
\hline Galicia & $-.625 * * *$ & $-.461 * * *$ & $-.664 * * *$ & $-.766 * * *$ & $.472^{* * *}$ & $-.244 * * *$ & $1.495^{*}$ & .973 \\
\hline Madrid & $-.242^{*}$ & $-.406 * *$ & .0955 & $-.280^{*}$ & .228 & -.00456 & .204 & .708 \\
\hline Murcia & $-.446 *$ & $-.609 * * *$ & $-.747 * * *$ & $-.822 * * *$ & $.222 *$ & $-.121 * *$ & $1.394^{*}$ & .967 \\
\hline Navarre & -.138 & $-.604 * * *$ & $-.897 * * *$ & $-.654 * * *$ & .159 & -.0448 & -.0739 & .935 \\
\hline $\begin{array}{l}\text { Basque } \\
\text { Country }\end{array}$ & $-.231^{*}$ & $-.362^{* *}$ & $-.844 * * *$ & $-.459 * * *$ & $.292 *$ & -.0231 & -.28 & .926 \\
\hline Rioja, La & $-.689 * *$ & -.24 & $-.620 * * *$ & $-.568 * * *$ & $.268^{*}$ & -.0376 & $1.938^{* *}$ & .929 \\
\hline Spain & $-.691 * * *$ & $-.444^{* *}$ & $-.644 * * *$ & $-.783 * * *$ & $.504^{* * *}$ & $-.154 * * *$ & $2.387^{* * *}$ & .984 \\
\hline
\end{tabular}

$* \mathrm{p}<0.10, * * \mathrm{p}<0.05, * * * \mathrm{p}<0.01$

(Aragon, Castile and Leon). The parameter accompanying gross national income resulted statistically significant in all cases, ranging from 0.517 in Andalusia to 0.222 in Murcia.

The fourth group is made up of regions with values more than 0.05 points below the average, but significantly different from 0 . These are the eastern regions of the Valencian Community and Catalonia.

Lastly, we have the regions where the EPU index did not turn out statistically significant: Extremadura, Basque Country, Navarre, La Rioja and Madrid. We remark the geographical grouping of the three middle ones and the peculiarities presented by the extremes. Moreover, four of these (all but Basque Country) have non-significant elasticities of overnight stays with respect to income - the only other cases where this is true is Catalonia in the previous grouping and the Balearic Islands. 
Figure 3 shows a map that depicts each of the groups identified above. Besides the Balearic archipelago, and with the exceptions of Castile-La Mancha, Madrid and Extremadura, there is a geographic continuity in the indicated categories. At this point, previous research has confirmed that Spanish regions are specialized in overnight stays of its own residents and neighbors (Benítez \& Cabrera, 2011). Our results have identified territorial groupings that react in a similar way to changes in the level of economic uncertainty. Very high indicates the only absolute value above 0.3 ; high indicates absolute values between 0.2-0.25; for moderate, between 0.1-0.19; for low, around 0.09; and around 0.05 or lower, values are non-significant.

Figure 3. Regions classified according to the elasticity of overnight stays of residents with respect to EPU index

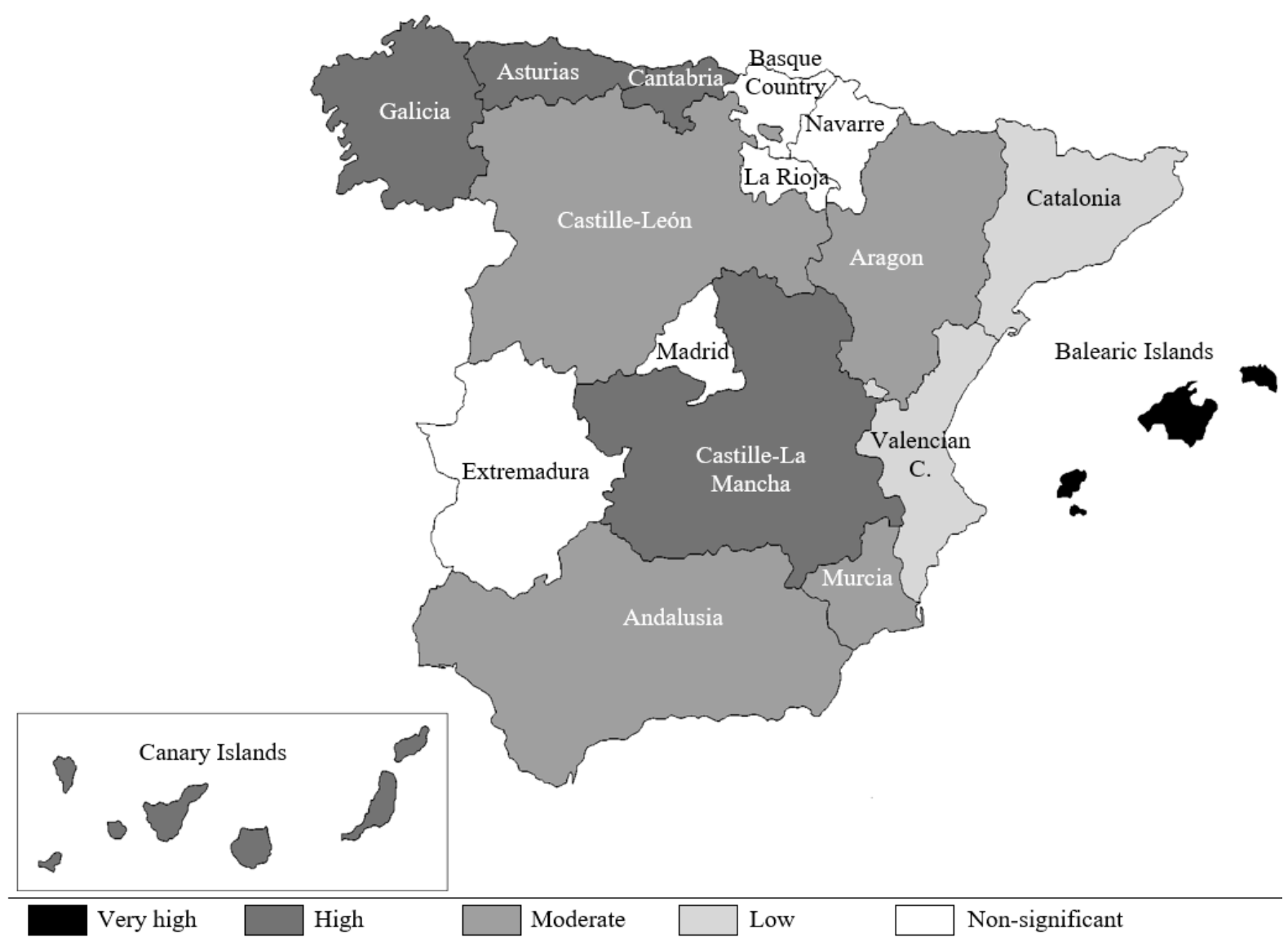

Source: Compiled from Table 2.

Finally, Figure 4 relates the number of overnight stays received per inhabitant for the whole period under consideration to the estimated elasticity parameter accompanying the EPU index. The trend line points to an inverse relationship between the two variables. That is, regions with a greater number of overnight stays per inhabitant tend to be more sensitive to economic uncertainty. Or, in other words, overnight stays in more touristic Communities are more likely to be impacted by alterations in uncertainty. 
Figure 4. Relationship between overnight stays of residents per inhabitant of each region, and its elasticity with respect to the EPU index

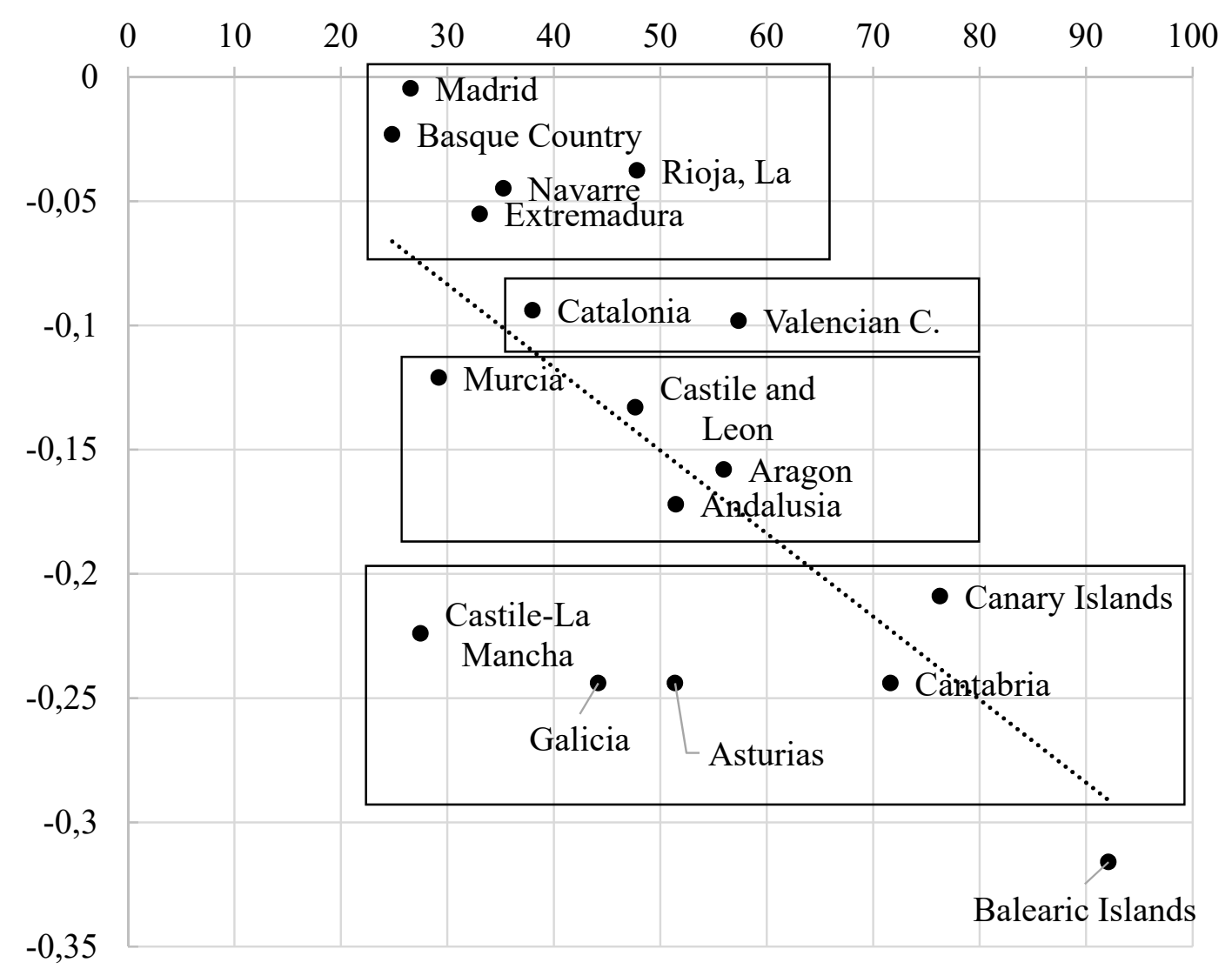

Source: Compiled from Table 2 and INE (2020d).

\section{CONCLUSIONS, IMPLICATIONS, LIMITATIONS AND FUTURE LINES OF RESEARCH}

Recently, econometric analyses have been made to demonstrate that tourist demand at an aggregate level falls when economic uncertainty grows. Our work, besides confirming that the EPU index is a statistically significant variable for Spain as a whole to explain changes in overnight stays of residents, exposes differentiated territorial patterns. Hence, tourist demand of residents of the Balearic Islands is relatively sensitive to changes in economic uncertainty. As for the rest of the regions, there are several geographic groupings in function of the elasticity of overnight stays with respect to uncertainty. The regions in which overnight stays varies substantially more than the national average when economic uncertainty in Spain changes form a very wide set that includes the northwestern Communities and Castile-La Mancha. Those with elasticity around the average are southern and inland northern regions; and substantially lower but significant are the eastern communities. Finally, Extremadura, the communities to the Center-North, and Madrid do not show a statistically significant relationship between the number of overnight stays of residents and economic uncertainty. Anyhow, it is observed that regions with a greater number of overnight stays per inhabitant are more sensitive to uncertainty variations. 
Our research illustrates, once again, the pertinence of applying a regional approach to nuance aggregate data. In the particular case of the analysis performed, it seems that in recent years, certain political events that occurred in Catalonia (that can be related to overall uncertainty growth in Spain) have introduced changes in tourist demand in other regions; and thus have generated spillover effects affecting the economic performance at a territorial levelin particular, in those Communities where tourism is deeply set. Consequently, we can draw implications from the point of view of policy, insofar as problems that emerge in particular regions (as well as the measures implemented for their solutions) can affect other regionsmore concretely, the production and employment associated to tourism.

The limitations of this work are related, to a large extent, to the scope of the analysis. Thus, the fact that we have utilized the overnight stays of residents in Spain conditions the generalization of the results at least in two senses. First, other types of overnight stays-such as those made in homes of family members or friends, or in peer-to-peer accommodation - have not been considered. On the other hand, we have not considered how economic uncertainty affects tourist demand of non-residents. At the same time, these limitations can be regarded to be opportunities for future lines of research where more complete tourist demand functions are to be estimated-both on the dependent variable side (including tourist expenditure, for instance) and on the independent variable side (considering the income of sending regions or countries, transportation costs, prices, or exchange rates, for the case of different currencies). In this context, new opportunities for research open up that involve a regional approach for the analysis of relationships between uncertainty and tourist demand. The first results are contained in this work.

\section{REFERENCES}

Ajogbeje, K., Adeniyi, O., \& Folarin, O. (2017). The effect of terrorism on tourism development in Nigeria: A note. Tourism Economics, 23(8), 1673-1678.

Ashraf, B.N., \& Shen, Y. (2019). Economic policy uncertainty and banks' loan pricing. Journal of Financial Stability, 44, 100695.

Aslan, A., \& Altinöz, B. (2020). The Nexus Between Economic Policy Uncertainty and Stock Returns of Tourism Companies: Evidence from Turkey. Tourism Review International, 23(3-4), 87-98.

Aye, G.C. (2018). Causality between economic policy uncertainty and real housing returns in emerging economies: A cross-sample validation approach. Cogent Economics \& Finance, 6(1), 1473708.

Baker, S.R., Bloom, N., \& Davis, S.J. (2016). Measuring economic policy uncertainty. The quarterly journal of economics, 131(4), 1593-1636.

Bassil, C., Hamadeh, M., \& Samara, N. (2015). The tourism led growth hypothesis: the Lebanese case. Tourism Review, 70(1), 43-55.

Bassil, C., Saleh, A.S., \& Anwar, S. (2019). Terrorism and tourism demand: A case study of Lebanon, Turkey and Israel. Current Issues in Tourism, 22(1), 50-70. 
Benítez Rochel, J.J., \& Cabrera Yeto, S. (2011). Análisis del turismo nacional en las comunidades autónomas peninsulares españolas: especialización y ventaja competitiva. Investigaciones Regionales-Journal of Regional Research, 20, 29-49.

Benítez-Aurioles, B. (2019a). Barcelona's peer-to-peer tourist accommodation market in turbulent times. International Journal of Contemporary Hospitality Management, 31(12), 4419-4437.

Benítez-Aurioles, B. (2019b). Transition costs and economic effects of the sovereignty process in Catalonia. Regional Science Policy \& Practice, 11(5), 821-832.

Bloom, N. (2009). The impact of uncertainty shocks. Econometrica, 77(3), 623-685.

Brogaard, J., \& Detzel, A. (2015). The asset-pricing implications of government economic policy uncertainty. Management Science, 61(1), 3-18.

Buigut, S. (2018). Effect of terrorism on demand for tourism in Kenya: A comparative analysis. Tourism and Hospitality Research, 18(1), 28-37.

Buigut, S., \& Amendah, D.D. (2016). Effect of terrorism on demand for tourism in Kenya. Tourism Economics, 22(5), 928-938.

Buigut, S., Braendle, U., \& Sajeewani, D. (2017). Terrorism and travel advisory effects on international tourism. Asia Pacific Journal of Tourism Research, 22(10), 991-1004.

Cheng, H.P., \& Yen, K.C. (2019). The relationship between the economic policy uncertainty and the cryptocurrency market. Finance Research Letters, 101308.

Chow, S.C., Cunado, J., Gupta, R., \& Wong, W. K. (2018). Causal relationships between economic policy uncertainty and housing market returns in China and India: Evidence from linear and nonlinear panel and time series models. Studies in Nonlinear Dynamics \& Econometrics, 22(2), 20160121.

Colombo, V. (2013). Economic policy uncertainty in the US: Does it matter for the Euro area?. Economics Letters, 121(1), 39-42.

Demir, E., \& Gözgör, G. (2018). Does economic policy uncertainty affect Tourism?. Annals of Tourism Research, 69(C), 15-17.

Dragouni, M., Filis, G., Gavriilidis, K., \& Santamaria, D. (2016). Sentiment, mood and outbound tourism demand. Annals of Tourism Research, 60, 80-96.

Economic Policy Uncertainty (2020). Spain Monthly Index. Available at https://www.policyuncertainty.com/spain GPU.html

Eeckhoudt, L., Gollier, C., \& Treich, N. (2005). Optimal consumption and the timing of the resolution of uncertainty. European Economic Review, 49(3), 761-773.

Enders, W., \& Sandler, T. (1991). Causality between transnational terrorism and tourism: The case of Spain. Studies in Conflict \& Terrorism, 14(1), 49-58.

Enders, W., Sandler, T., \& Parise, G. F. (1992). An econometric analysis of the impact of terrorism on tourism. Kyklos, 45(4), 531-554.

Feridun, M. (2011). Impact of terrorism on tourism in Turkey: empirical evidence from Turkey. Applied Economics, 43(24), 3349-3354.

Fleischer, A., \& Buccola, S. (2002). War, terror, and the tourism market in Israel. Applied Economics, 34(11), 1335-1343.

Ghaderi, Z., Saboori, B., \& Khoshkam, M. (2017). Does security matter in tourism demand?. Current Issues in Tourism, 20(6), 552-565. 
Ghirelli, C., Pérez, J.J., \& Urtasun, A. (2019). A new economic policy uncertainty index for Spain. Economics Letters, 182, 64-67.

Giavazzi, F., \& McMahon, M. (2012). Policy uncertainty and household savings. Review of Economics and Statistics, 94(2), 517-531.

Gozgor, G., \& Ongan, S. (2017). Economic policy uncertainty and tourism demand: Empirical evidence from the USA. International Journal of Tourism Research, 19(1), 99-106.

Ongan, S., \& Gozgor, G. (2018). Tourism demand analysis: The impact of the economic policy uncertainty on the arrival of Japanese tourists to the USA. International Journal of Tourism Research, 20(3), 308-316.

Hsieh, H.C., Boarelli, S., \& Vu, T.H.C. (2019). The effects of economic policy uncertainty on outward foreign direct investment. International Review of Economics \& Finance, 64, 377-392.

INE (2020a). Encuesta de Ocupación Hotelera. Available at https://ine.es/dyngs/ INEbase/es/operacion.htm?c=Estadistica C\&cid $=1254736177015 \&$ menu $=$ ultiDatos\&idp $=1254735576863$

INE (2020b). Contabilidad nacional trimestral de España. Available at https://ine.es/dyngs/ INEbase/es/operacion.htm?c=Estadistica C\&cid=1254736164439\&menu=ultiDatos\&idp $=1254735576581$

INE (2020c). Estadística de Empleo Turístico según la EPA. Available at http://estadisticas. tourspain.es/es-es/estadisticas/otrasestadisticas/empleoturistico/encuestapoblacion/ paginas/trimestrales.aspx

INE (2020d). Cifras de población. Available at https://ine.es/dyngs/INEbase/es/operacion. htm?c=Estadistica C\&cid=1254736176951\&menu=ultiDatos\&idp=1254735572981

Işik, C., Sirakaya-Turk, E., \& Ongan, S. (2019). Testing the efficacy of the economic policy uncertainty index on tourism demand in USMCA: Theory and evidence. Tourism Economics, 1354816619888346.

Ivanovski, K., \& Churchill, S.A. (2019). Economic policy uncertainty and demand for money in Australia. Applied Economics, 51(41), 4516-4526.

Karl, M., Winder, G., \& Bauer, A. (2017). Terrorism and tourism in Israel: Analysis of the temporal scale. Tourism Economics, 23(6), 1343-1352.

Karnizova, L., \& Li, J.C. (2014). Economic policy uncertainty, financial markets and probability of US recessions. Economics Letters, 125(2), 261-265.

Keynes, J.M. (1936). The General Theory of Employment, Interest and Money. London: Macmillan.

Li, X. L., Li, X., \& Si, D.K. (2020). Investigating asymmetric determinants of the CNY-CNH exchange rate spreads: The role of economic policy uncertainty. Economics Letters, 186, 108827.

Liu, A., \& Pratt, S. (2017). Tourism's vulnerability and resilience to terrorism. Tourism Management, 60, 404-417.

Llorca-Vivero, R. (2008). Terrorism and international tourism: New evidence. Defence and Peace Economics, 19(2), 169-188.

Ma, R., Zhou, C., Cai, H., \& Deng, C. (2019). The forecasting power of EPU for crude oil return volatility. Energy Reports, 5, 866-873. 
Madanoglu, M., \& Ozdemir, O. (2018). Economic policy uncertainty and hotel operating performance. Tourism Management, 71, 443-452.

Morales, L., \& Andreosso-O'Callaghan, B. (2019). Challenges and Opportunities Brought to the Chinese Economy by Brexit and the New US Administration. Journal of Emerging Market Finance, 0972652719846304.

Neumayer, E. (2004). The impact of political violence on tourism: Dynamic cross-national estimation. Journal of conflict resolution, 48(2), 259-281.

Neumayer, E., \& Plümper, T. (2016). Spatial spill-overs from terrorism on tourism: Western victims in Islamic destination countries. Public Choice, 169(3-4), 195-206.

Nilavongse, R., Michał, R., \& Uddin, G.S. (2020). Economic policy uncertainty shocks, economic activity, and exchange rate adjustments. Economics Letters, 186, 108765.

Pesaran, M. H., Y. Shin, and R. Smith (2001). Bounds testing approaches to the analysis of level relationships. Journal of Applied Econometrics, 16(3), 289-326.

Pizam, A., \& Fleischer, A. (2002). Severity versus frequency of acts of terrorism: Which has a larger impact on tourism demand?. Journal of Travel research, 40(3), 337-339.

Raza, S.A., \& Jawaid, S.T. (2013). Terrorism and tourism: A conjunction and ramification in Pakistan. Economic Modelling, 33, 65-70.

Saha, S., \& Yap, G. (2014). The moderation effects of political instability and terrorism on tourism development: A cross-country panel analysis. Journal of Travel Research, 53(4), 509-521.

Samitas, A., Asteriou, D., Polyzos, S., \& Kenourgios, D. (2018). Terrorist incidents and tourism demand: Evidence from Greece. Tourism management perspectives, 25, 23-28.

Thompson, A. (2011). Terrorism and tourism in developed versus developing countries. Tourism Economics, 17(3), 693-700.

Tremblay, P. (1989). Pooling international tourism in Western Europe. Annals of Tourism Research, 16(4), 477-491.

Tsui, W.H.K., Balli, F., Tan, D.T.W., Lau, O., \& Hasan, M. (2018). New Zealand business tourism: Exploring the impact of economic policy uncertainties. Tourism Economics, 24(4), 386-417.

White, K. J. (1985). An international travel demand model US travel to Western Europe. Annals of Tourism Research, 12(4), 529-545.

Yaya, M.E. (2009). Terrorism and tourism: The case of Turkey. Defence and Peace Economics, 20(6), 477-497.

Yin, D.A.I., Zhang, J. W., Yu, X. Z., \& Xin, L.I. (2017). Causality between economic policy uncertainty and exchange rate in China with considering quantile differences. Theoretical \& Applied Economics, 24(3), 29-38. 